\title{
Partial mowing of urban lawns supports higher abundances and diversities of insects
}

\author{
Jennifer Wintergerst ${ }^{1}\left(\mathbb{D} \cdot\right.$ Tommy Kästner $^{2} \cdot$ Manuela Bartel $^{3} \cdot$ Christian Schmidt $^{3} \cdot$ Matthias Nuss $^{3}$ (이
}

Received: 11 December 2020 / Accepted: 4 June 2021 / Published online: 6 September 2021

(c) The Author(s) 2021

\begin{abstract}
Within the citizen science project "Flowering meadows for Saxonian butterflies", more than 640 meadows are partially and at maximum three times annually mowed in order to change urban lawns into habitats for insects. In 2019, insect diversity was evaluated using the 100 sweep net technique during five visits at nine butterfly meadows (BM) and nine intensively mowed lawns (IML). The mean arthropod biomass of these five visits per site is significantly higher on BM compared to IML. All adult individuals of Apidae, Coleoptera, Heteroptera, Orthoptera, Papilionoidea as well as Asilidae and Syrphidae have been identified morphologically, revealing 260 species from all study sites. The mean number of species per visit is significantly higher on BM compared to IML. 90 species are recorded as larva and the mean number of species per visit is significantly higher on BM compared to IML. 42 species are recorded as larva as well as adult. The records of larvae provide evidence for reproduction on the meadows.

Implications for insect conservation Our results clearly demonstrate that a reduced mowing frequency together with an always partial mowing of the area support higher biomass, abundances and diversities of insects as well as reproduction of insects on urban lawns. Therefore, reduced mowing frequency together with partial mowing is recommended for urban lawns as well as meadows in the countryside and conservation areas to foster insect diversity.
\end{abstract}

Keywords Urban lawns $\cdot$ Mowing $\cdot$ Insects $\cdot$ Biodiversity $\cdot$ Abundance $\cdot$ Adults $\cdot$ Larvae $\cdot$ Apidae $\cdot$ Coleoptera $\cdot$ Heteroptera $\cdot$ Orthoptera $\cdot$ Papilionoidea $\cdot$ Asilidae $\cdot$ Syrphidae

\section{Introduction}

Matthias Nuss

matthias.nuss@senckenberg.de

Jennifer Wintergerst

jennifer.wintergerst@web.de

Tommy Kästner

info@icarus-umweltplanung.de

Manuela Bartel

manuela.bartel@senckenberg.de

Christian Schmidt

christian.schmidt@senckenberg.de

Johann-Meyer-Str. 22, 01097 Dresden, Germany

2 icarus Umweltplanung, Clausen-Dahl-Str. 43, 01219 Dresden, Germany

3 Senckenberg Museum of Zoology Dresden, Königsbrücker Landstraße 159, 01109 Dresden, Germany
Urban lawns fulfil different functions for human recreation (White et al. 2013; Tsurumi and Managi 2015), but a large part of these areas is not used at all despite intensive mowing. Modern rotary mowers immediately taking up the yield are used up to 14 times per year and lawn, including in autumn in order to remove fall foliage. The lawns are usually mowed over their entire area during each treatment. As a result, there is hardly any time and space left for the development of most insects.

There is an increasing awareness for the potential that urban lawns can have for plant and insect diversity. Giuliano et al. (2004) found that park size, field size, and plant species richness are positively related to lepidopteran abundance in New York City parks. In contrast, only a weak species-arearelationship was found for grassland plants and Hemiptera in urban roundabouts in the U.K., whereas species richness was significantly affected by the type of mowing (Helden and Leather 2004). In Finland, road verges with delayed and 
partial mowing had higher species richness and abundance of butterflies and diurnal moths, compared to mid-summer and late-summer complete mowing (Valtonen et al. 2006). Noordijk et al. (2009) also investigated different mowing managements of road verges in the Netherlands and found that mowing twice per year with removal of hay showed highest values for numbers of flower species and inflorescences as well as total abundance of insects and actual flower visits. Also, the early summer cut proved to be very important for insect feeding opportunities, due to the reflowering of plants later in the growing season. Nevertheless, these plots were entirely devoid of flowers for some period right after mowing (Noordijk et al. 2009). In Paris, small public gardens that employed a conservation program such as zero pesticide and adaptive mowing practices as well as introducing sub-habitats such as ponds, flower meadows and unmanaged patches supported a higher diversity of insects and birds (Shwartz et al. 2013). Garbuzov et al. (2014) applied four different mowing regimes in a suburban public park in Saltdean, UK. They found 50 times greater insect abundance in that area of the park which has been not mowed for a year, while significantly lowest abundance was found where regular mowing took place every two weeks during spring and summer. Regular mowing regimes until June 2nd and July 5th were intermediate. A mowing management comprising only one or two mowing events per year and the removal of the mown grass from the surface is applied in the city of Tübingen, Germany since 2010. It significantly increases the diversity indices of orthopterans, butterflies, hemipterans and bees (Hiller and Betz 2014; Kricke et al. 2014; Unterweger et al. 2017; Wastian et al. 2016). Also, the change from mowing lawns every few weeks to mowing only once or twice per season results already after six years in an increase of the number of plant species by $30 \%$ and the species composition is shifting from common mowing-tolerant lawn species to typical meadow species (Sehrt et al. 2020). This confirms results from the city of Rennes in France where plant diversity increased by $15 \%$ to $62 \%$ after 25 years of reduced mowing frequency.

Higher insect diversity indices have been also found in Switzerland (Braschler et al. 2009; Humbert et al. 2012a; Buri et al. 2013; Bruppacher et al. 2016) and the Czech Republic (Cizek et al. 2012) in non-urban grasslands which are less often mowed and at which spatial adaptations on the mowing management are incorporated, though some studies show diverging results for different taxa (Braschler et al. 2003, 2016). In contrast, different scheduling of mowing had little or no effect on insect diversity (Humbert et al. 2012b).

Here, we investigated the effect of reduced mowing frequency and partial mowing of lawns to analyse the potential that urban lawns may have for different groups of insects. Beside adults, we were particularly interested in the possible occurrence of insect larvae, as their occurrence provide evidence of local reproduction.

\section{Material and methods}

\section{The Butterfly meadows project}

The original title of the public project in German is 'Puppenstuben gesucht-Blühende Wiesen für Sachsens Schmetterlinge'. The first part of the title means "Dollhouses wanted". It is a pun, as the word "Puppe" in German means doll, but also chrysalis (pupa) and so the project is looking for places where chrysalises can stay. The second part of the title means 'Flowering meadows for Saxonian butterflies'. The project started in 2015 focussing on urban lawns which are not used for recreation. People are called to apply a management comprising at maximum three times mowing per year and leaving each time 10-30\% of the lawn uncut (called 'partial mowing' in the present paper). The uncut part moves among mowing events. An explanatory movie is available at http://schnellebuntebilder.de/projects/schmetterlingswiesen (in English). Until 2020, 640 'butterfly meadows' with an average size of $3.814 \mathrm{~m}^{2}$ have been registered for this activity. These meadows are managed by 500 users, e.g. private persons, companies, schools, hospitals and local authorities. On the project web-site www.schmetterlingswiesen.de (in German), participants are welcome to write a blog about the activities on their meadows and to document the sightings of plants and animals, particularly insects. In December 2018, an external evaluation was conducted with the focus on the motivations for volunteering in this project (Moczek 2019; Moczek et al. 2021).

\section{Study sites}

Nine butterfly meadows (BM) and nine intensively managed lawns (IML) in or near the city of Dresden were studied. The mowing of the BM constitutes of the combination of (1) at maximum three times mowing per year, (2) leaving each time $10-30 \%$ of the lawn uncut, which also includes the winter season (the unmowed part rotates during each treatment), (3) mulch is not allowed, rotary machines are allowed and bar mowers are recommended as well as (4) the removal of the mown grass is mandatory. There is no instruction for scheduling the mowing events and the margins of some BM are cut more often in order to gain public acceptance easier.

The IML usually experiences a higher number of mowing events, each with a clear cut of the entire area. Each $\mathrm{BM}$ has an individual number, under which detailed information can be found at www.schmetterlingswiesen.de. These numbers are also used in the following. The code 
Table 1 Location of sampling sites and their mowing regimes in 2019, partially mowed means that 10 to 30 percent per mowing event remain unmown

\begin{tabular}{lllllll}
\hline Type & Meadow number & Northern latitude & Eastern longitude & $\begin{array}{l}\text { n Times } \\
\text { mowed }\end{array}$ & $\begin{array}{l}\text { Partially } \\
\text { mowed }\end{array}$ & Size in $\mathrm{m}^{2}$ \\
\hline BM & 12 & 51.1289 & 13.7903 & 0 & - & 2030 \\
IML & 12 & 51.1295 & 13.7933 & 4 & No & 2038 \\
BM & 48 & 51.0492 & 13.7746 & 1 & Yes & 2010 \\
IML & 48 & 51.0493 & 13.7769 & 4 & No & 960 \\
BM & 131 & 51.0191 & 13.7284 & 0 & - & 726 \\
IML & 131 & 51.0179 & 13.7285 & 5 & No & 815 \\
BM & 144 & 51.0422 & 13.7067 & 1 & Yes & 1360 \\
IML & 144 & 51.0475 & 13.7089 & 4 & No & 965 \\
BM & 192 & 51.0283 & 13.7388 & 1 & Yes & 1245 \\
IML & 192 & 51.0286 & 13.7421 & 4 & No & 1346 \\
BM & 246 & 50.8941 & 13.7590 & 2 & Yes & 3460 \\
IML & 246 & 50.8933 & 13.7575 & 5 & No & 1745 \\
BM & 272 & 51.0150 & 13.6319 & 1 & Yes & 960 \\
IML & 272 & 51.0145 & 13.6359 & 5 & No & 3000 \\
BM & 1708 & 50.9860 & 13.5887 & 0 & - & 1715 \\
IML & 1708 & 50.9866 & 13.5853 & 2 & No & 3210 \\
BM & 1885 & 50.9400 & 13.7914 & 1 & Yes & 2275 \\
IML & 1885 & 50.8937 & 13.7583 & 5 & No & 1460 \\
\hline
\end{tabular}

numbers of the IML start with an "N", followed by the number of the nearest BM. Table 1 shows location and mowing regime of the investigated meadows.

\section{Sampling}

Each study site has been visited five times from the end of May until the beginning of August 2019. During each visit, sweep netting (Marchand 1953; Schwoerbel 1957; Witsack 1975; Schuch et al. 2012) with 100 sweeps was carried out. Contents of the sweep net were killed with cyanide and afterwards weighed (fresh weight-before being preserved further) with a fine scale, in order to record the arthropod biomass per 100 sweeps. Every visit took place under similar conditions. Sampling has been carried out between $10 \mathrm{a} . \mathrm{m}$. and 5 p.m. as well as under weather conditions recommended by the butterfly monitoring (Sevilleja et al. 2019). Adults of Papilionoidea and Apidae were placed in paper bags or pinned, respectively. All other adults are stored in $80 \%$ isopropanol. Larvae were preserved in $100 \%$ ethanol. A sixth survey from 2 nd to 6th September 2019 focused on Orthoptera by visual and acoustical identification in the field as well as by sweep netting through vegetation, aiming at a comprehensive inventory of species at each meadow. In addition to the insect recording, all herbaceous plants at blossom were recorded on BM during each visit. Since the IML were mowed very shortly and hardly any herbaceous plants at blossom except daisies (Bellis perennis) and dandelions (Taraxacum officinale agg.) could be found, we refrained from recording plant species on IML.

\section{Morphological identification of species}

Adult Apidae, Coleoptera, Heteroptera, Orthoptera, Papilionoidea as well as Asilidae and Syrphidae were identified morphologically, if necessary, preparation of genitalia was made.

The following literature was used for identification of the adults: Apidae: Dathe (1980), Amiet (1996), Amiet et al. (1999), Amiet et al. (2001), Amiet et al. (2004), Amiet et al. (2007), Amiet et al. (2010). Asilidae: Wolff et al. 2018. Coleoptera: Harde (1966), Mohr (1966), Fürsch (1967), Vogt (1967), von Peez (1967), Ermisch (1969), Kaszab (1969), Machatschke (1969), Evers (1979), Harde (1979), Lohse (1979), Brandl (1981), Kippenberg (1981), Lohse (1981), Kippenberg (1983), Lohse (1983a), Lohse (1983b), Lohse and Tischler (1983), Novak (1986), Audisio (1993), Behne (1994), Warchalowski (2003), Zapata de la Vega and Sánchez-Ruiz (2003), Odnosum (2004), Bezděk and Baselga (2015), Caldara and Legalov (2016). Heteroptera: Wagner (1952), Wagner (1961), Wagner (1966), Wagner (1967), Péricart (1972), Péricart (1983), Moulet (1995), Péricart (1998a), Péricart (1998b), Péricart (1998c) Matocq (2004), Derjanschi and Péricart (2005), Kment and Bryja (2006), Aglyamzyanov (2009), Putshkov and Moulet (2009), 
Namyatova (2010), Kment and Bryja (2012), Matocq and Pluot-Sigwalt (2012), Lupoli et al. (2013), Ribes and PagolaCarte (2013). Lepidoptera: Settele et al. (2015). Orthoptera: Bellmann (2004), Fischer et al. (2016). Syrphidae: Haarto and Kerppola (2007), Bartsch et al. (2009a, b), Speight and Sarthou (2016).

Female syrphids of the genera Paragus, Pipizella and Sphaerophoria cannot be identified morphologically. In all these cases, males were recorded and identified at species level, and the females were linked to these species for reasons of parsimony. All other specimens that could only be identified at genus level are listed as "sp." and in all those cases these were single individuals per genus.

Insect specimens are preserved in the collections of Tommy Kästner (Asilidae), Jennifer Wintergerst (Apidae) and all the remaining groups at the Senckenberg Museum of Zoology Dresden.

Plant species were identified using Jäger (2011).

\section{DNA extraction, PCR, sequencing and species level identification based on the DNA-Barcode}

DNA barcoding (Hebert et al. 2003, 2004) was applied for species identification of larvae. All larvae are individually analysed. For DNA extraction whole larvae smaller than $2 \mathrm{~mm}$ or small pieces of tissue of larger larvae were used. The DNA was isolated using the Macherey-Nagel Nucleospin ${ }^{\circledR}$ tissue-kit (Düren, Germany) according to instructions. For PCR, we used the primer LCO1490-JJ / HCO2198-JJ (Astrin and Stüben 2008) or HybLCO/ HybHCO with a universal primer tail (T7/T3) for sequencing (Wahlberg and Wheat 2008). PCR was carried out in $25 \mu 1$ batches with DFS-Taq (Bioron, Roemerberg, Germany) and $5 \mu 1$ undiluted DNA. Deviating from the user manual, $1 \mu \mathrm{l}$ $\mathrm{MgCl} 2(50 \mathrm{mM})$ and $0.25 \mu \mathrm{lBA}(20 \mathrm{ng} / \mu \mathrm{l})$ were added to the PCR. The PCR program was: step 1: $5 \mathrm{~min}$ at $95^{\circ} \mathrm{C}$; step 2: $95^{\circ} \mathrm{C}$ at $0: 30 \mathrm{~min}, 49^{\circ} \mathrm{C}$ at $0: 30 \mathrm{~min}, 72^{\circ} \mathrm{C}$ at $1: 00 \mathrm{~min}$ in 39 cycles and step 3: $72^{\circ} \mathrm{C}$ at $10 \mathrm{~min}$. PCR results were checked on a $2 \%$ agarose gel. For sequencing we used the EZ-Seq service from Macrogen europe (Netherlands). Samples were sequenced forwards by standard (sequencing primer: LCO1490-JJ or T7), reverse-sequencing (sequencing primer: HCO2198-JJ or T3) applied in some cases only. Sequences were quality checked using the Chromas program (technelysium, version 2.6.6). Obtained sequences were used to search in the identification engine of the Barcode of Life Data System (BOLD) Version 4 (as of November 2019) for species-level identification (Ratnasingham and Hebert 2007, 2013). Sequence matches with Sequence identity greater than $99 \%$ were accepted as species identification. In nine cases, we obtained over $99 \%$ sequence matches with two species each and eventually determined the species after verifying the voucher specimens morphologically.

\section{Statistical analyses}

If not otherwise stated, the analyses are based on the results from the 100-sweep net method. Species diversity is analyzed using the Shannon Index and comparison of meadows to show their similarity in species inventory by the Sørensen-Dice quotient (Dice 1945; Sørensen 1948). Mean biomass, mean number of species and Shannon Index showed no normal distribution and were therefore statistically analyzed with Mann-Whitney-U-Tests to show if there are any significant differences between butterfly meadows and intensely mowed lawns. All statistical explorations, tests, boxplots and other graphics were created with RStudio (R Core Team 2019) using packages ggplot2 (Wickham 2016), and dismo (Hijmans et al. 2017).

\section{Results}

\section{Citizen Science data.}

Thanks to the observations recorded by the participants on the project website, we learned that insects are coming back already during the first season during which the mowing regime is adapted. After the first three seasons of the project, citizen science data were available for 77 meadows and the most common butterflies sighted were Maniola jurtina (number of observations $=66$ ), Coenonympha pamphilus $(\mathrm{n}=57)$, Polyommatus icarus $(\mathrm{n}=57)$, Pieris rapae $(\mathrm{n}=52)$, Pieris napi $(\mathrm{n}=48)$, Aphantopus hyperantus $(\mathrm{n}=46)$, Aglais io $(\mathrm{n}=39)$, Pieris brassicae $(\mathrm{n}=35)$, Thymelicus lineola $(\mathrm{n}=30)$ and Araschnia levana $(\mathrm{n}=28)$.

\section{Arthropod biomass}

The mean arthropod biomass of five visits per meadow ranges from $1.26-4.51 \mathrm{~g}$ on the $\mathrm{BM}$ as well as from 0.01-0.33 g on the IML (Fig. 1, online resource 1). The mean biomass of $\mathrm{BM}$ is significantly higher than that of IML (Mann-Whitney-U-Test, N=9, p < 0.01). The outliers are based on a high abundance of orthopterans on BM 1708 and a high abundance of honeybees on IML 1708.

\section{Adults}

Using the 100-sweep net method, a total of 260 species based on adult individuals were identified morphologically from all study sites across all groups (Table 2, online resource 2). The mean number of species per visit on the BM ranges from 13.6-24.8 species and is significantly higher than the mean number of species on the IML, which ranges 
Fig. 1 Mean biomass of five visits per meadow, separated by $\mathrm{BM}$ and IML
Table 2 Number of insect species per BM and IML

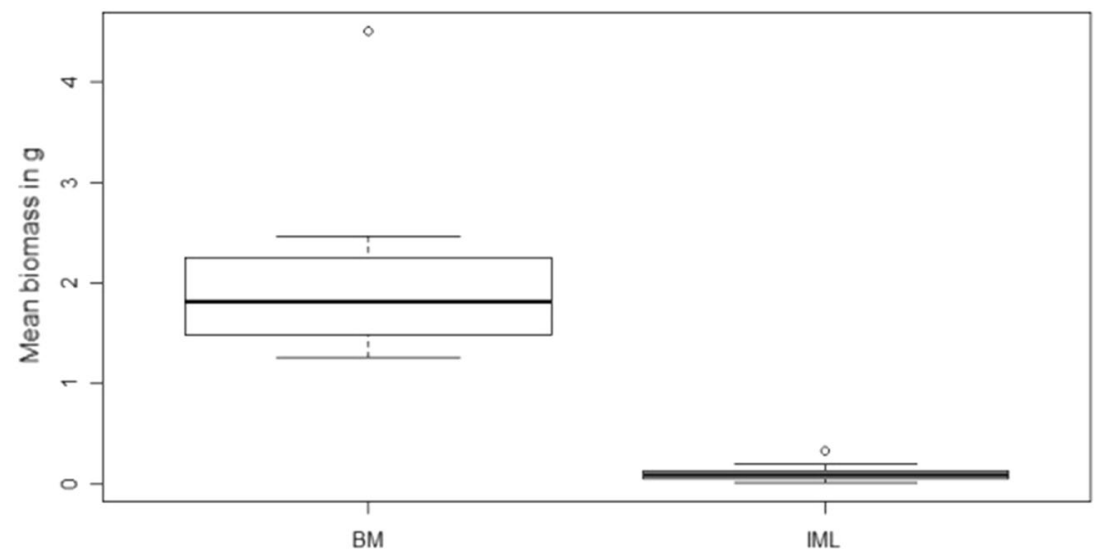

\begin{tabular}{llllllllll}
\hline Type & Nr & Api & Asi & Col & Het & Pap & Ort & Syr & total \\
\hline BM & 12 & 11 & 3 & 26 & 24 & 7 & 1 & 5 & 77 \\
BM & 48 & 22 & 0 & 14 & 12 & 1 & 3 & 5 & 57 \\
BM & 131 & 13 & 0 & 9 & 21 & 2 & 1 & 3 & 49 \\
BM & 144 & 16 & 0 & 20 & 20 & 5 & 2 & 9 & 72 \\
BM & 192 & 19 & 1 & 24 & 24 & 5 & 3 & 1 & 77 \\
BM & 246 & 7 & 1 & 28 & 19 & 11 & 4 & 8 & 78 \\
BM & 272 & 12 & 0 & 18 & 22 & 5 & 2 & 7 & 66 \\
BM & 1708 & 13 & 3 & 26 & 23 & 5 & 6 & 7 & 83 \\
BM & 1885 & 8 & 2 & 17 & 13 & 2 & 6 & 5 & 53 \\
IML & 12 & 0 & 0 & 0 & 0 & 0 & 2 & 0 & 2 \\
IML & 48 & 0 & 0 & 0 & 2 & 0 & 0 & 0 & 2 \\
IML & 131 & 0 & 0 & 0 & 0 & 0 & 1 & 0 & 1 \\
IML & 144 & 2 & 0 & 1 & 3 & 0 & 0 & 0 & 6 \\
IML & 192 & 0 & 0 & 2 & 0 & 0 & 0 & 0 & 2 \\
IML & 246 & 0 & 0 & 0 & 0 & 1 & 1 & 0 & 2 \\
IML & 272 & 0 & 0 & 2 & 0 & 1 & 1 & 0 & 4 \\
IML & 1708 & 2 & 0 & 1 & 2 & 1 & 1 & 3 & 10 \\
IML & 1885 & 0 & 0 & 0 & 0 & 0 & 0 & 0 & 0 \\
Sum & & 57 & 6 & 90 & 64 & 16 & 10 & 17 & 260 \\
\hline
\end{tabular}

Api Apidae, Asi Asilidae, Col Coleoptera, Het Heteroptera, Pap Papilionoidea, Ort Orthoptera, Syr Syrphidae

from 0-3 species (Mann-Whitney-U-Test, $\mathrm{N}=9, \mathrm{p}<0.01$ ) (Fig. 2).

There are 10 orthopteran species recorded by sweep netting (Online resource 2 ) and 13 by the sixth survey for orthoptera (Online resource 3 ). Two species were only recorded by sweep net, five species only by acoustic and visual method. In total, 15 species were recorded on all study sites. The total number of orthopteran species on BM ranges from 4-11 and is significantly higher than the total number of species on the IML ranging from 1-5 (Mann-WhitneyU-Test, $\mathrm{N}=9, \mathrm{p}<0.01$ ) (Fig. 3).

The Shannon-Index on BM ranges from 4.63-5.81 and is significantly higher on the BM than on the IML ranging from 0.00-3.08 (Mann-Whitney-U-Test, $\mathrm{N}=9, \mathrm{p}<0.01$ ) (Fig. 4).

The mean Sørensen-Dice coefficient is $35.98 \%$ among BM (Table 3). 127 of the recorded 260 species only occur on one single meadow. In contrast, only three species (Apis mellifera, Chorthippus biguttulus, Sphaerophoria scripta) were recorded on all nine butterfly meadows (Fig. 5).

\section{Larvae}

90 species were identified based on individuals in their larval stage. 86 of these species were recorded from BM, two species from IML and two species from both, BM and 
Fig. 2 Mean number of adult insect species of five visits per meadow, separated by BM and IML

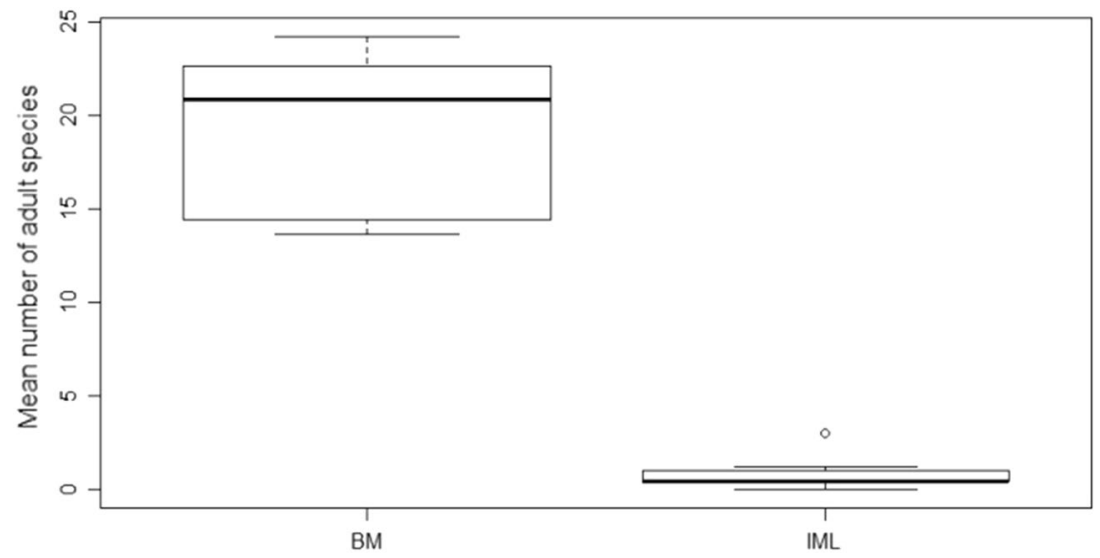

Fig. 3 Total number of adult species of Orthoptera of five visits using sweep netting plus the sixth survey per meadow, separated by BM and IML
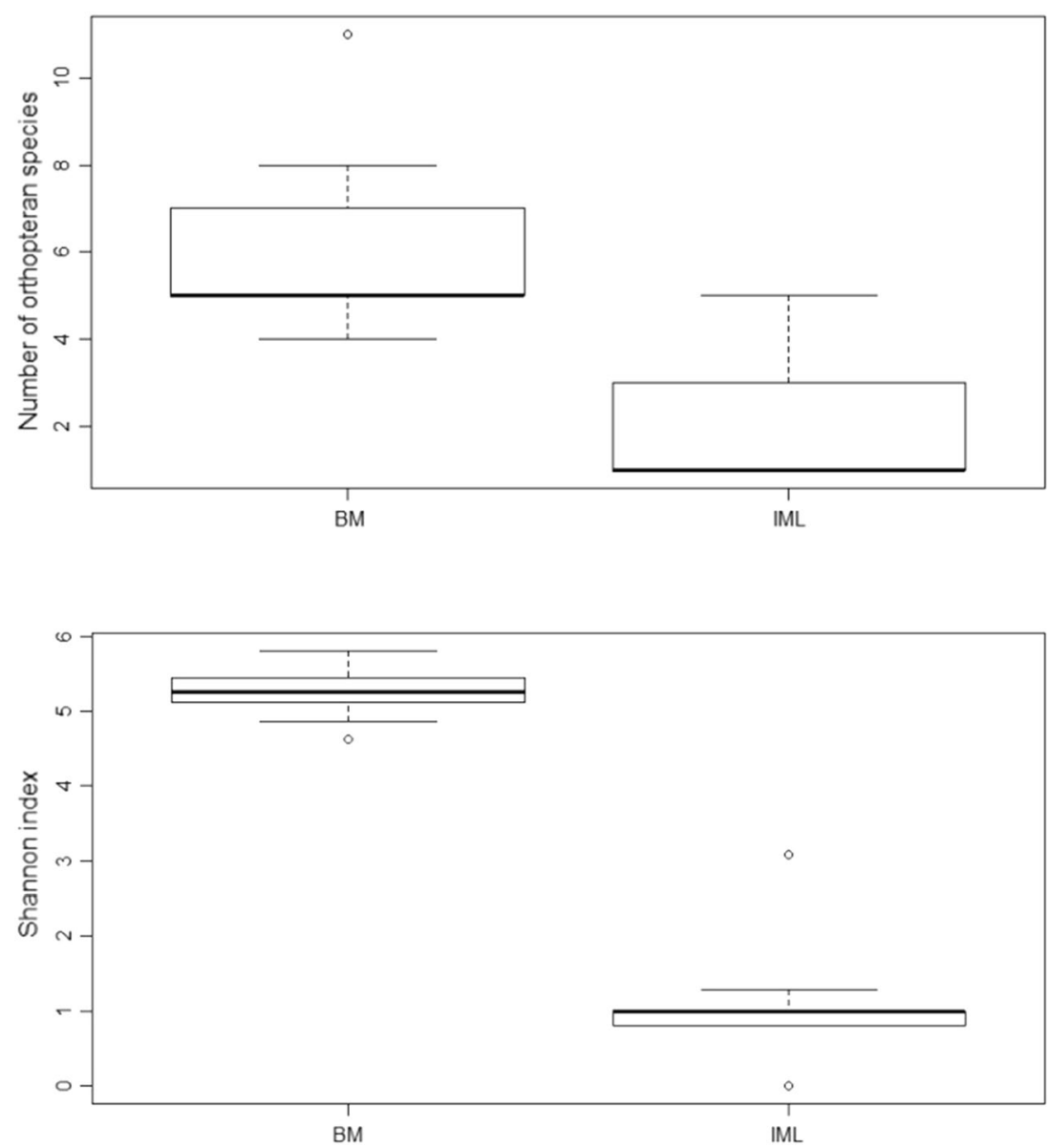

IML (Online resource 4). 42 of these species were also recorded as adults (compare online resource 2). No larvae were recorded by sweep netting for Apidae, Papilionoidea, Asilidae and Syrphidae.

The mean number of larval species per visit on the BM ranges from 2.4-8.6 species and is significantly higher than the mean number of species on the IML, which ranges from 0-0.4 species (Mann-Whitney-U-Test, $\mathrm{N}=9$, $\mathrm{p}<0.01$ ) (Fig. 6).
The mean Sørensen-Dice coefficient regarding the larval inventory is $23.05 \%$ (Table 4 ).

\section{Number of plant species}

136 herbaceous plant species at blossom were recorded on the butterfly meadows (Online resource 5). The mean Sørensen-Dice coefficient regarding the plant species inventory is $39.49 \%$ (Table 5). 
Table 3 Sørensen-Dice coefficient insect species in adult stage among BM

\begin{tabular}{llllllllll}
\hline & 12 & 48 & 131 & 144 & 192 & 246 & 272 & 1708 & 1885 \\
\hline 12 & & & & & & & & & \\
48 & 31.58 & & & & & & & \\
131 & 27.20 & 28.30 & & & & & & \\
144 & 35.14 & 29.46 & 31.40 & & & & & \\
192 & 37.09 & 37.88 & 41.94 & 29.93 & & & & \\
246 & 34.21 & 31.58 & 28.80 & 33.78 & 37.09 & & & \\
272 & 37.76 & 32.26 & 44.83 & 34.53 & 43.66 & 37.76 & & \\
1708 & 38.75 & 32.62 & 34.59 & 34.62 & 42.77 & 46.25 & 46.36 & \\
1885 & 35.66 & 38.18 & 25.49 & 35.20 & 37.50 & 38.76 & 40.00 & 42.34 \\
Mean & 35.98 & & & & & & & \\
\hline
\end{tabular}

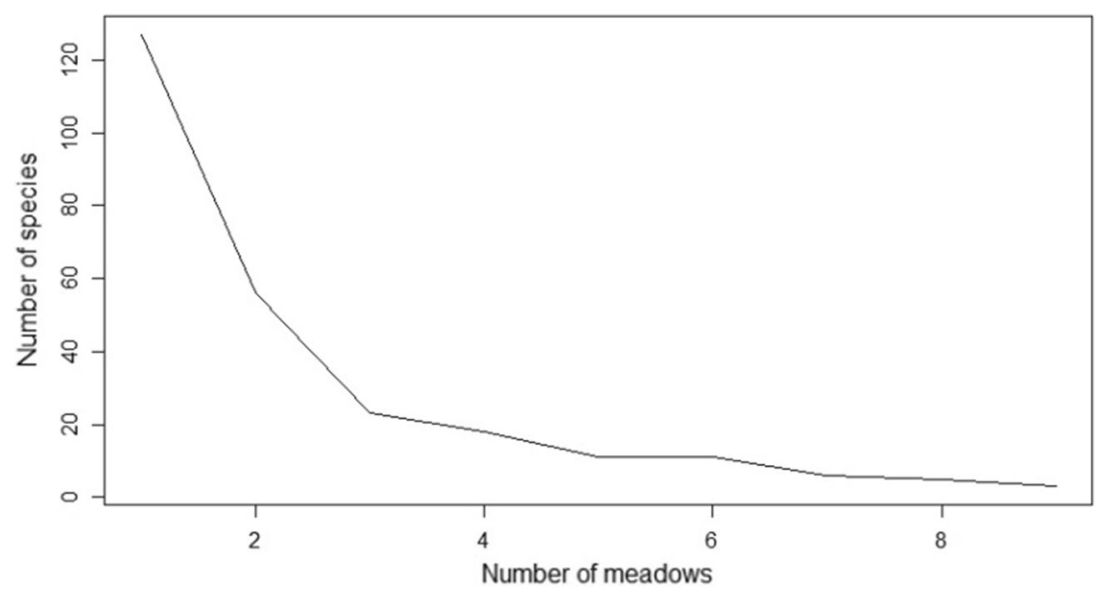

Fig. 5 Number of species depending on the number of meadows from which they were recorded

Fig. 6 Mean number of species recorded in their larval stage during five visits using sweep netting per meadow, separated by BM and IML

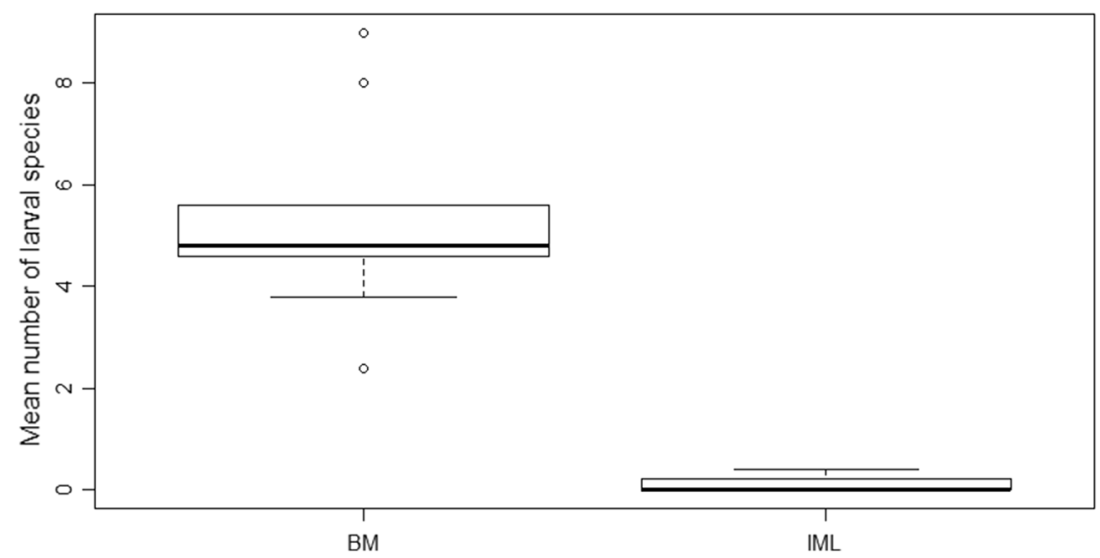

\section{Discussion}

The results show significantly higher arthropod biomass and $\alpha$-diversity of insects on butterfly meadows compared to intensively mowed lawns. Significantly higher are also the records of insect larvae on butterfly meadows, placing evidence that these meadows are habitats for reproduction for a number of insect species. The data strongly support the results achieved for orthopterans by Humbert et al. (2012a) and Buri et al. (2013) that a reduced number of mowing events together with partial mowing coincides with significantly higher biomass as well as number of insect species in their adult and larval stages. 
Table 4 Sørensen-Dice coefficient of species recorded in their larval stage on BM
Table 5 Sørensen-Dice coefficient of herbaceous plant species at blossom on $\mathrm{BM}$

\begin{tabular}{lllrllllll}
\hline & 12 & 48 & 131 & 144 & 192 & 246 & 272 & 1708 & 1885 \\
\hline 12 & & & & & & & & & \\
48 & 32.00 & & & & & & & \\
131 & 24.39 & 20.69 & & & & & & \\
144 & 21.82 & 32.56 & 11.76 & & & & & \\
192 & 28.57 & 32.43 & 21.43 & 28.57 & & & & \\
246 & 22.22 & 33.33 & 18.18 & 25.53 & 19.51 & & & \\
272 & 13.33 & 24.24 & 8.33 & 21.05 & 31.25 & 21.62 & & \\
1708 & 36.92 & 30.19 & 27.27 & 31.03 & 23.08 & 45.61 & 25.00 & \\
1885 & 15.38 & 22.22 & 22.22 & 18.75 & 14.29 & 12.12 & 8.33 & 4.55 \\
Mean & 23.05 & & & & & & & & \\
\hline
\end{tabular}

\begin{tabular}{llllllllll}
\hline & 12 & 48 & 131 & 144 & 192 & 246 & 272 & 1708 & 1885 \\
\hline 12 & & & & & & & & & \\
48 & 62.61 & & & & & & & \\
131 & 51.49 & 32.69 & & & & & & \\
144 & 51.85 & 59.46 & 53.61 & & & & & \\
192 & 57.14 & 53.19 & 50.00 & 41.38 & & & & \\
246 & 35.42 & 44.44 & 16.47 & 30.43 & 34.67 & & & \\
272 & 32.69 & 42.99 & 32.26 & 36.00 & 28.92 & 34.09 & & \\
1708 & 45.28 & 58.72 & 35.79 & 43.14 & 42.35 & 42.22 & 44.90 & \\
1885 & 25.35 & 29.73 & 20.00 & 23.88 & 20.00 & 40.00 & 25.40 & 43.08 \\
Mean & 39.49 & & & & & & & \\
\hline
\end{tabular}

The Sørensen-Dice coefficient demonstrates a moderate similarity of species composition for adult insects (mean $35.98 \%$ ) as well as for plants (mean 39.49\%). The coefficient is slightly lower when looking at the larvae alone, which can be explained by the fact that the larvae of some species groups cannot be detected with the applied method due to their occurrence in the lower vegetation like nocturnal larvae of satyrine butterflies or in the soil like endogeic bees. The coefficient may refer to different sets of requisites on the meadows, but it has also been taken into account that the 100 sweeps do not take a complete inventory of a given meadow and therefore different parts of the species communities might have been taken. A complete recording of all species would take more time for field and laboratory work. Since hundreds of meadows are already registered in the project and their number is still increasing, we are searching for even less time consuming methods in order to evaluate insect diversity. With regard to the goal of the project and the intention of the volunteers managing the meadows for supporting insects, such a method should be even non-invasive. Examples are the Butterfly Monitoring counting individuals along a transect (Van Swaay et al. 2012) or acoustic monitoring of orthopterans (Fischer et al. 1997; Gardiner et al. 2005; Lehmann et al. 2014).
The analysed insect groups comprise the main pollinator groups bees, beetles, butterflies and hover flies as well as representatives of the main trophic groups plant feeders (Apidae, Coleoptera part, Heteroptera, Orthoptera, Papilionoidea), predators (Asilidae, Syrphidae part, Coccinellidae) and saprophages (Syrphidae part). Among bees, most species are polyphagous, while some are oligophagous like Andrena hattorfiana on Dipsacaceae and Colletes fodiens on Asteraceae and also the cuckoo bees are well presented. In Orthoptera, the recorded species are predominantly generalists, but provide some information regarding the mowing regime. A few species are indicators for some structural diversity of vegetation (Conocephalus fuscus, Leptophyes albovittata), dry conditions (Chorthippus mollis) or moisture (Stetophyma grossum). Orthopteran larvae were only recorded on BMs. The resettlement of meadows takes place by macropteres, especially if adjacent populated areas are absent, which is very often the case in an urban setting. The recorded presence of brachypteres is interpreted as resettlement by macropteres in preceding years. Roeseliana roeselii is only recorded by brachypteres on BM which are extensively managed already for a longer period or where there are adjacent areas which are not intensively mowed (BM 246, 272, 1708, 1885). Chorthippus parallelus is missing 
on intensively mowed lawns. On BM, it is predominantly recorded by brachypteres and few macropteres that are able for resettlement. In contrast, the winged Chorthippus biguttulus is present in low numbers even on intensively mowed lawns and with high numbers on BM. BM 1885 is an orchard which could have a much higher number of species, but is dominated by grasses with tendencies to fallow. BM 1708 has been known from earlier years during which more species were present that are now missing, e.g. Phaneroptera falcata, Conocephalus fuscus, Chorthippus albomarginatus, Chorthippus brunneus (Kästner, unpubl.). These two BM represent the often observed tendency in the project that people mow not often enough or do not mow at all, which results in effects of fallow and reduced species diversity. This points to the necessity to communicate that some mowing is required in order to prevent a meadow from becoming fallow ground.

We found the highest biomass (mean $4.5 \mathrm{~g}$ ) and highest species number (83 spp.) on BM 1708 which is also used as a pasture, pointing to the fact that low-intensity grazing can favour an even higher insect diversity due to inconsistent food uptake, disruption of vegetation and placement of excrements.

The successful running of the project achieving hundreds of BMs in Saxony might still be regarded as a starting point as the majority of urban lawns is still intensively mowed. As an example, the city of Dresden is responsible for 1.438 ha of urban green spaces, of which 674 ha comprise lawns, meadows and pastures (Jähnigen communication by letter, 2020) which indeed is still a huge potential to promote insect diversity by reducing the number of mowing events together with partial mowing.

The overall recommendations for the management of urban lawns in order to promote insect diversity are in line with several previous authors. First, the reduction of mowing frequency (Valtonen et al. 2006; Noordijk et al. 2009; Garbuzov et al. 2014; Hiller and Betz 2014; Kricke et al. 2014; Unterweger et al. 2017; Wastian et al. 2016; Braschler et al. 2009; Humbert et al. 2012a; Buri et al. 2013; Bruppacher et al. 2016; Cizek et al. 2012; Braschler et al. 2003, 2016) extends the time window during which plants and insects can develop. Depending on the plant growth rate, two to three mowing events per year are required in order to prevent fallow as well as to maintain a meadow rich in herbal species and with sunlight reaching to the ground. One mowing event per year might be sufficient only on very nutrient poor, sandy soils if nitrogen immission is low. Second, it is advantageous to leave the cut grass for a few days only and harvest it as hay (Valtonen et al. 2006; Noordijk et al. 2009; Garbuzov et al. 2014; Hiller and Betz 2014; Kricke et al. 2014; Unterweger et al. 2017; Wastian et al. 2016; Humbert et al. 2012a; Cizek et al. 2012). It enables the subsequent ripening, falling out and distribution of seeds on the area. Insects can leave the cuttings and move to uncut areas or to the edges of the meadow. Third, every time an area is mowed, a part should be left uncut (Valtonen et al. 2006; Braschler et al. 2009; Humbert et al. 2012a; Buri et al. 2013; Kricke et al. 2014; Bruppacher et al. 2016; Cizek et al. 2012; Braschler et al. 2003, 2016). We recommend to leave an uncut area of about 30\% during each mowing event. Here, plants and insects can continue their development. This also applies for winter to allow hibernation. The uncut area rotates with every mowing event in order to prevent fallow. Fourth, wherever possible, low intensity grazing with livestock should be applied as it promotes seed dispersal by livestock, structural diversification of the vegetation cover and development of a dung fauna (Conradi 2010; Rada et al. 2014; Christé et al. 2016; Tälle et al. 2016).

In order to achieve that the adaptive management of urban lawns is applied to as many areas as possible, it must be taken into account that the lawns have different owners, e.g. private persons, companies, schools, hospitals and local authorities. In our opinion, a public project like "Flowering meadows for Saxonian butterflies" is ideally suitable to reach different stakeholders, providing basic information on the ecology of plants and insects, as well as the necessity of an adaptive management. The knowledge is transferred via the project webpage, prints, public talks and workshops. The latter also allows to learn about knowledge gaps and practical problems of different stakeholders as well as to develop together possible solutions, like a sample specification of services for local authorities. The public awareness also contributed to introduce partial mowing in actions funded by the European Agricultural Fund for Rural Development (EAFRD). In Saxony, it is allowed since 2018 to leave less than $10 \%$ of meadows uncut when EAFRD funds are taken. This positively affects meadows in nature protected areas, which have been regularly completely mowed during the last decades.

Supplementary Information The online version contains supplementary material available at https://doi.org/10.1007/s10841-021-00331-w.

Acknowledgements We are grateful to all people involved in the butterfly meadow project.André Reimann (Senckenberg Museum of Zoology Dresden, SMTD) and Wolf-Harald-Liebig (Bad Muskau) kindly reviewed the identification of hoverfly and bee species, respectively. We are grateful to Eva Jähnigen, Mayor of the Environment and Local Government of the city of Dresden for interesting discussion and providing information on the green spaces of the city. We very much appreciated discussions with our colleague Raffael Ernst (SMTD). The results presented here were made possible through financial support from the Saxon State Ministry for Energy, Climate Protection, Environment and Agriculture. We would also like to thank two anonymous reviewers for their constructive advice on the manuscript.

Authors' contributions Jennifer Wintergerst and Matthias Nuss contributed to the overall study's conception, design and field work, Tommy 
Kästner contributed to the conception, design and field work of the additional survey on orthopterans. Material preparation, species identification and data collection were accordingly performed by all authors, but Christian Schmidt identified the Coleoptera and Heteroptera und Manuela Bartel did the lab work and identification based on the DNA barcodes. The first draft of the manuscript was written by Jennifer Wintergerst and Matthias Nuss and all authors commented on previous versions of the manuscript. All authors read and approved the final manuscript.

Funding Open Access funding enabled and organized by Projekt DEAL. The investigations were made possible by financial support from the Saxon State Ministry for Energy, Climate Protection, Environment and Agriculture.

Availability of data and material Sequence data of specimens is available in BOLD, see online resource 4 for process IDs.

Code availability Not applicable.

\section{Declarations}

Conflict of interest The authors declare that they have no conflict of interest.

\section{Consent to participate Not applicable.}

Consent for publication Not applicable.

Ethical approval Sampling of insects is permitted by Nature conservation authorities for Matthias Nuss by the city of Dresden (document 86.44-12-0299/21680 33,529/17) and for Tommy Kästner by the district of Sächsische Schweiz-Osterzgebirge (Saxon Switzerland-Eastern Ore Mountains) (document 343-Wo-621).

Open Access This article is licensed under a Creative Commons Attribution 4.0 International License, which permits use, sharing, adaptation, distribution and reproduction in any medium or format, as long as you give appropriate credit to the original author(s) and the source, provide a link to the Creative Commons licence, and indicate if changes were made. The images or other third party material in this article are included in the article's Creative Commons licence, unless indicated otherwise in a credit line to the material. If material is not included in the article's Creative Commons licence and your intended use is not permitted by statutory regulation or exceeds the permitted use, you will need to obtain permission directly from the copyright holder. To view a copy of this licence, visit http://creativecommons.org/licenses/by/4.0/.

\section{References}

Aglyamzyanov R (2009) Revision der paläarktischen Arten der Gattung Lygus Hahn, 1833 (Heteroptera: Miridae). Entomol Zool 119(6):249-276

Amiet F (1996) Apidae 1. Allgemeiner Teil, Gattungsschlüssel, die Gattungen Apis, Bombus und Psithyrus. Fauna Insecta 12. CSCF \& SEG, Neuchâtel

Amiet F, Müller A, Neumeyer R (1999) Apidae 2. Colletes, Dufourea, Hylaeus, Nomia, Rhophitoides, Rophites, Sphecodes, Systropha. Fauna Helvetica 4. CSCF \& SEG, Neuchâtel
Amiet F, Herrmann M, Müller A, Neumayer R (2001) Apidae 3. Halictus, Lasioglossum. Fauna Helvetica 6. CSCF \& SEG, Neuchâtel

Amiet F, Herrmann M, Müller A, Neumayer R (2004) Apidae 4. Anthidium, Chelostoma, Coelioxys, Dioxys, Heriades, Lithurgus, Megachile, Osmia, Stelis. Fauna Helvetica 9. CSCF \& SEG, Neuchâtel

Amiet F, Herrmann M, Müller A, Neumayer R (2007) Apidae 5. Ammobates, Ammobatoides, Anthophora, Biastes, Ceratina, Dasypoda, Epeoloides, Epeolus, Eucera, Macropis, Melecta, Melitta, Nomada, Pasites, Tetralonia, Thyreus, Xylocopa. Fauna Helvetica 20. CSCF \& SEG, Neuchâtel

Amiet F, Herrmann M, Müller A, Neumayer R (2010) Apidae 6. Andrena, Melitturga, Panurginus, Panurgus. Fauna Helvetica 20. CSCF \& SEG, Neuchâtel

Astrin JJ, Stüben PE (2008) Phylogeny in cryptic weevils: molecules, morphology and new genera of western Palaearctic Cryptorhynchinae (Coleoptera:Curculionidae). Invertebr Syst 22:503-522

Audisio P (1993) Coleoptera, Nitidulidae - Kateretidae. Fauna d'Italia 32:i-xvi, 1-971

Bartsch H, Binkiewicz E, Klintbjer A, Radén A, Nasibov E (2009a) Tvåvingar: Blomflugor. Diptera: Syrphidae: Eristalinae \& Microdontinae. Artdatabanken, Sveriges lantbruksuniversitet, Uppsala

Bartsch H, Binkiewicz E, Radén A, Nasibov E (2009b) Tvåvingar: Blomflugor. Diptera: Syrphidae: Syrphinae. Artdatabanken, Sveriges lantbruksuniversitet, Uppsala

Behne L (1994) Familie: Apionidae. In: Freude H, Harde KW, Lohse GA (eds) Die Käfer Mitteleuropas 14. Springer, Berlin, pp $184-246$

Bellmann, H (2004) Heuschrecken—Die Stimmen von 61 heimischen Arten. CD-ROM. Musikverlag Edition Ample

Bezděk J, Baselga A (2015) Revision of western Palaearctic species of the Oulema melanopus group, with description of two new species from Europe (Coleoptera: Chrysomelidae: Criocerinae). Acta Ent Mus Nat Prag 55(1):273-304

Brandl P (1981) Familie: Bruchidae (Samenkäfer). In: Freude H, Harde KW, Lohse GA (ed) Die Käfer Mitteleuropas 10, Goecke \& Evers, Krefeld, pp7-21

Braschler B, Baur B (2003) Effects of experimental small-scale grassland fragmentation on spatial distribution, density, and persistence of ant nests. Ecol Ent 28(6):651-658

Braschler B, Baur B (2016) Diverse Effects of a Seven-Year Experimental Grassland Fragmentation on Major Invertebrate Groups. PLoS ONE 11(2):e0149567

Braschler B, Marini L, Thommen GH, Baur B (2009) Effects of smallscale grassland fragmentation and frequent mowing on population density and species diversity of orthopterans: a long-term study. Ecol Entomol 34(3):321-329

Bruppacher L, Pellet J, Arlettaz R, Humbert JY (2016) Simple modifications of mowing regime promote butterflies in extensively managed meadows: evidence from field-scale experiments. Biol Conserv 196:196-202

Buri P, Arlettaz R, Humbert JY (2013) Delaying mowing and leaving uncut refuges boosts orthopterans in extensively managed meadows: evidence drawn from field-scale experimentation. Agric Ecosyst Environ 181:22-30

Caldara R, Legalov AA (2016) Systematics of the Holarctic species of the weevil genus Cleopomiarus Pierce (Coleoptera: Curculionidae). J Insect Biodivers 4(6):1-47

Chisté MN, Mody K, Gossner MM, Simons NK, Köhler G, Weisser WW, Blüthgen N (2016) Losers, winners, and opportunists: how grassland land-use intensity affects orthopteran communities. Ecosphere 7(11):e01545

Cizek O, Zamecnik J, Tropek R, Kocarek P, Konvicka M (2012) Diversification of mowing regime increases arthropods diversity in species-poor cultural hay meadows. J Insect Conserv 16:215-226 
Chollet S, Brabant C, Tessier S, Jung V (2018) From urban lawns to meadows: from urban lawns to urban meadows: reduction of mowing frequency increases plant taxonomic, functional and phylogenetic diversity. Landsc Urban Plan 180:121-124

Conradi M (2010) Livestock excrement: a neglected habitat. In: Plachter H, Hampicke U (eds) Large-scale livestock grazing. A management tool for nature conservation. Springer, pp 118-127

Dathe HH (1980) Die Arten der Gattung Hylaeus F. in Europa (Hymenoptera: Apoidea, Colletidae). Mitt Zool Mus 56(2):207-294

Derjanschi V, Péricart J (2005) Hémiptères Pentatomoidea Euro-Méditerranéens, vol 1, pp 1-494

Dice LR (1945) Measures of the amount of ecologic association between species. Ecology 26(3):297-302

Ermisch K (1969) Fam. Mordellidae. In: Freude H, Harde KW, Lohse GA (ed) Die Käfer Mitteleuropas. Goecke \& Evers, Krefeld, pp 108-196

Evers AMJ (1979) Fam. Malachiidae. In: Freude H, Harde KW, Lohse GA (ed) Die Käfer Mitteleuropas 6, Goecke \& Evers, Krefeld, pp 53-69

Fischer FP, Schulz U, Schubert H, Knapp P, Schmöger M (1997) Quantitative assessment of grassland quality: acoustic determination of population sizes of orthopteran indicator species. Ecol Appl 7:909-920

Fischer J, Steinlechner D, Zehm A, Poniatowski D, Fartmann T, Beckmann A, Stettmer C (2016) Die Heuschrecken Deutschlands und Nordtirols. Quelle \& Meyer, Wiebelsheim

Fürsch H (1967) Coccinellidae. In: Freude H, Harde KW, Lohse GA (eds) Die Käfer Mitteleuropas 7, Goecke \& Evers, Krefeld, pp 227-278

Garbuzov M, Fensome KA, Ratnieks FLW (2014) Public approval plus more wildlife: twin benefits of reduced mowing of amenity grass in a suburban public park in Saltdean, UK. Insect Conserv Divers 8:107-119

Gardiner T, Hill J, Chesmore D (2005) Review of the methods frequently used to estimate the abundance of Orthoptera in grassland ecosystems. J Insect Conserv 9:151-173

Giuliano WM, Accamando AK, Mcadams EJ (2004) Lepidopterahabitat relationships in urban parks. Urban Ecosyst 7:361-370

Haarto A, Kerppola S (2007) Finnish hoverflies and some species in adjacent countries. Otavan Kirjaoaino Oy, Keuruu

Harde KW (1966) Familie: Cerambycidae. In: Freude H, Harde KW, Lohse GA (eds) Die Käfer Mitteleuropas 9, Goecke \& Evers, Krefeld, pp 7-94

Harde KW (1979) Fam. Buprestidae. In: Freude H, Harde KW, Lohse GA (eds) Die Käfer Mitteleuropas 6. Goecke \& Evers, Krefeld, pp 204-230

Hebert PDN, Ratnasingham S, de Waard JR (2003) Barcoding animal life: cytochrome $\mathrm{c}$ oxidase subunit 1 divergences among closely related species. Proc Biol Sci 270(Suppl 1):96-99

Hebert PDN, Stoeckle MY, Zemlak TS, Francis CM (2004) Identification of birds through DNA barcodes. PLoS Biol 2(10):e312

Helden AJ, Leather SR (2004) Biodiversity on urban roundabouts Hemiptera, management and the species-area relationship. Basic appl Ecol 5(4):367-377

Hijmans RJ, Phillips S, Leathwick J, Elith J (2017). dismo: Species Distribution Modeling. R package version 1.1-4. https:// CRAN.R-project.org/package $=$ dismo

Hiller D, Betz O (2014) Auswirkungen verschiedener Mahdkonzepte auf die Heuschreckenfauna städtischer Grünflächen. Nat Landsc 46(8):241-246

Humbert JY, Ghazoul J, Richner N, Walter T (2012a) Uncut grass refuges mitigate the impact of mechanical meadow harvesting on orthopterans. Biol Conserv 152:96-101

Humbert JY, Pellet J, Buri P, Arlettaz R (2012b) Does delaying the first mowing date benefit biodiversity in meadowland? Environ Evid 1:9
Jäger E (2011) Rothmaler: Exkursionsflora von Deutschland. Gefäßpflanzenband: Grundband. 20., neu bearbeitete und erweiterte Auflage. Spektrum Akademischer Verlag, Heidelberg

Kaszab Z (1969) Familie Alleculidae. In: Freude H, Harde KW, Lohse GA (ed) Die Käfer Mitteleuropas 8, Goecke \& Evers, Krefeld, pp 215-229

Kippenberg H (1981) Familie Curculionidae. In: Freude H, Harde KW, Lohse GA (eds) Die Käfer Mitteleuropas 10. Springer, Berlin Heidelberg, pp 102-111

Kippenberg H (1983) Unterfamilie Hylobiinae. In: Freude H, Harde KW, Lohse GA (ed.) Die Käfer Mitteleuropas 11 Springer, Berlin, pp 121-154

Kment P, Bryja J (2006) Revised occurrence of Heterotoma species (Heteroptera: Miridae) in the Czech Republic and Slovakia with remarks on nomenclature, diagnostic characters and ecology. Acta Mus Morav Sci Biol (brno) 91:7-52

Kment P, Bryja J (2012) Erratum: Kment, P. \& Bryja, J. 2006. Revised occurrence of Heterotoma species (Heteroptera: Miridae) in the Czech Republic and Slovakia with remarks on nomenclature, diagnostic characters and ecology. Acta Mus Morav. Sci Biol (brno) 91:7-52

Kricke C, Bamann T, Betz O (2014) Einfluss städtischer Mahdkonzepte auf die Artenvielfalt der Tagfalter. Nat Landsc 46(2):52-58

Lehmann GUC, Frommolt KH, Lehmann AW, Riede K (2014) Baseline data for automated acoustic monitoring of Orthoptera in a Mediterranean landscape, the Hymettos, Greece. J Insect Conserv 18:909-925

Lohse GA (1979) Familie: Elateridae. In: Freude H, Harde KW, Lohse GA (ed) Die Käfer Mitteleuropas 6. Goecke \& Evers, Krefeld, pp 103-186

Lohse GA (1981) Unterfamilie Rhynchitidae. In: Freude H, Harde KW, Lohse GA (ed) Die Käfer Mitteleuropas 10, Goecke \& Evers, Krefeld, pp 113-124

Lohse GA (1983a) Unterfamilie Curculioninae. In: Freude H, Harde KW, Lohse GA (ed) Die Käfer Mitteleuropas 11, Goecke \& Evers, Krefeld, pp 78-110

Lohse GA (1983b) Unterfamilie Ceutorhynchinae. In: Freude H, Harde KW, Lohse GA (ed) Die Käfer Mitteleuropas 11, Goecke \& Evers, Krefeld, pp 180-253

Lohse GA, Tischler T (1983) Unterfamilie Ceutorhynchinae. In: Freude H, Harde KW, Lohse GA (ed) Die Käfer Mitteleuropas 11. Goecke \& Evers, Krefeld, pp 259-283

Lupoli R, Dusoulier F, Cruaud A, Cros-Arteil S, Streito JC (2013) Morphological, biogeographical and molecular evidence of Carpocoris mediterraneus as a valid species (Hemiptera: Pentatomidae). Zootaxa 3609(4):392-410

Marchand H (1953) Die Bedeutung der Heuschrecken und Schnabelkerfe als Indikatoren verschiedener Graslandtypen. Beitr Ent $3: 116-162$

Machatschke JW (1969) Familienreihe Lamellicornia. In: Freude H, Harde KW, Lohse GA (eds) Die Käfer Mitteleuropas 8. Goecke \& Evers, Krefeld, pp 265-371

Matocq A (2004) Revue des espèces attribuées au genre Megalocoleus Reuter, 1890 (Heteroptera: Miridae). Annales De La Société Entomologique De France 40(1):69-101

Matocq A, Pluot-Sigwalt D (2012) Révision des Amblytylus et essai de mise au point sur les genres Amblytylus Fieber et Megalocoleus Reuter (Heteroptera: Miridae: Phylinae). Ann Soc Entomol Fr 48(1-2):123-154

Moczek N (2019) Freiwilliges Engagement für Citizen ScienceProjekte im Naturschutz. Konstruktion und Validierung eines Skalensystems zur Messung motivationaler und organisationaler Funktionen. Pabst Science Publishers, Lengerich

Moczek N, Nuss M, Köhler JK (2021) Volunteering in the citizen science project "Insects of Saxony"- - the larger the island of knowledge, the longer the bank of questions. Insects 12(3):262 
Mohr KH (1966) Familie: Chrysomelidae. In: Freude H, Harde KW, Lohse GA (ed) Die Käfer Mitteleuropas 9. Goecke \& Evers, Krefeld, pp 95-280

Moulet P (1995) Hémiptères Coreoidea (Coreidae, Rhopalidae, Alydidae), Pyrrhocoridae, Stenocephalidae Euro-Méditerranéens. Faune De France 81:1-336

Namyatova AA (2010) Revision of the genus Pachytomella (Heteroptera: Miridae: Orthotylinae: Halticini). Acta Ent Mus Nat Prag 50(2):341-368

Noordijk J, Delille K, Schaffers AP, Sýkora KV (2009) Optimizing grassland management for flower-visiting insects in roadside verges. Biol Conserv 142:2097-2103

Novak G (1986) Über die Trennung von Anthaxia quadripunctata Linné und Anthaxia godeti Castelnau et Gory (Coleoptera, Buprestidae). Z Arbeitsgem Österr Ent 38(1/2):xx

Odnosum VK (2004) Mordellid Beetles of the Genus Mordella (Coleoptera, Mordellidae) of Central and Eastern Palaearctics. Vestn Zool 38(6):15-28

Péricart J (1972) Hémiptères Anthocoridae, Cimicidae et Microphysidae de l'Ouest-Paléarctique. Faune de l'Europe et du bassin méditerranéen 7:1-402

Péricart J (1983) Hémiptères Tingidae Euro-méditerranéens. Faune de France 69:i-ix + 1-620

Péricart J (1998a) Hémiptères Lygaeidae euro-méditerranéens, Volume 1. Faune de France 84 A:i-xx:1-468

Péricart J (1998b) Hémiptères Lygaeidae euro-méditerranéens, Volume 2. Faune de France 84 B:i-iii:1-453

Péricart J (1998c) Hémiptères Lygaeidae euro-méditerranéens, Volume 3. Faune de France 84 C:i-vi:1-487

Putshkov PV, Moulet P (2009) Hémiptères Reduviidae d'Europe occidentale. Faune De France 92:1-668

Rada S, Mazalová M, Šipos J, Kuras T (2014) Impacts of mowing, grazing and edge effect on Orthoptera of submontane grasslands: perspectives for biodiversity protection. Polish Jl Ecol 62:123-138

Ratnasingham S, Hebert PD (2007) BOLD: the barcode of life data system (http://www.barcodinglife.org). Mol Ecol Notes 7(3):355-364

Ratnasingham S, Hebert PDN (2013) A DNA-Based Registry for All Animal Species: The Barcode Index Number (BIN) System. PLoS ONE 8(1):3

R Core Team (2019) R: a language and environment for statistical computing. Vienna, Austria: R Foundation for statistical Computing. Retrieved from https://www.R-project.org/

Ribes J, Pagola-Carte S (2013) Hémiptères Pentatomoidea EuroMéditerranéens. Vol. 2: Pentatominae (suite). Faune De France 96:1-423

Schuch S, Wesche K, Schaefer M (2012) Long-term decline in the abundance of leafoppers and planthoppers (Auchenorrhyncha) in Central European protected dry grasslands. Biol Conserv 149(1):75-83

Sehrt M, Bossdorf O, Freitag M, Bucharova A (2020) Less is more! Rapid increase in plant species richness after reduced mowing in urban grasslands. Basic Appl Ecol 42:47-53

Shwartz S, Muratet A, Simon L, Julliard R (2013) Local and management variables outweigh landscape effects in enhancing the diversity of different taxa in a big metropolis. Biol Conserv 157:285-292

Schwoerbel W (1957) Die Wanzen und Zikaden des Spitzberges bei Tübingen - eine faunistisch-ökologische Untersuchung. Z Morph Ökol Tiere 45:462-560

Settele J, Steiner R, Reinhardt R, Feldmann R, Herrmann G (2015) Schmetterlinge - Die Tagfalter Deutschlands. Ulmer Verlag, Stuttgart

Sevilleja CG, van Swaay CAM., Bourn N, Collins S, Settele J, Warren MS, Wynhoff I, Roy DB (2019) Butterfly Transect Counts:
Manual to monitor butterflies. Report VS2019.016, Butterfly Conservation Europe \& De Vlinderstichting/Dutch Butterfly Conservation, Wageningen

Sørensen T (1948) A method of establishing groups of equal amplitude in plant sociology based on similarity of species and its application to analyses of the vegetation on Danish commons. Danske Videnskab Selskab, Biol Skr 5(4):1-34

Speight MCD, Sarthou JP (2016) StN keys for the identification of the European species of various genera of Syrphidae 2016. Syrph the Net, the database of European Syrphidae (Diptera), Vol. 92. Syrph the Net publications, Dublin

Tälle M, Deák B, Poschlod P, Valkó O, Westerberg L, Milberg P (2016) Grazing vs. mowing: a meta-analysis of biodiversity benefits for grassland management. Agric Ecosyst Environ 222:200-212

Tsurumi T, Managi S (2015) Environmental value of green spaces in Japan: an application of the life satisfaction approach. Ecol Econ 120:1-12

Unterweger PA, Rieger C, Betz O (2017) The influence of urban lawn mowing regimes on diversity of Heteroptera (Hemiptera). Heteropteron 48:7-21

Valtonen A, Saarinen K, Jantunen J (2006) Effect of different mowing regimes on butterflies and diurnal moths on road verges. Anim Biodiv Conserv 29:133-148

Van Swaay CAM, Brereton T, Kirkland P, Warren MS (2012) Manual for Butterfly Monitoring. Report VS2012.010, Dutch Butterfly Conservation, Butterfly Conservation UK \& Butterfly Conservation Europe, Wageningen

Vogt H (1967) Fam. Phalacridae. In: Freude H, Harde KW, Lohse GA (ed) Die Käfer Mitteleuropas 7. Goecke \& Evers, Krefeld, pp 158-166

von Peez A (1967) Familie: Lathridiidae. In: Freude H, Harde KW, Lohse GA (ed) Die Käfer Mitteleuropas 7, Goecke \& Evers, Krefeld, pp 168-190

Wagner E (1952) Blindwanzen oder Miriden. Die Tierwelt Deutschlands 41:i-iv:1-218

Wagner E (1961) Heteroptera - Hemiptera. Die Tierwelt Mitteleuropas 4 Lief. 3 Heft 10a:1-173

Wagner E (1966) Wanzen oder Heteroptera. I. Pentatomorpha. Die Tierwelt Deutschlands 54. Teil:i-vi:1-235

Wagner E (1967) Wanzen oder Heteropteren. II Cimicomorpha Die Tierwelt Deutschlands 55:1-179

Wahlberg N, Wheat CW (2008) Genomic outposts serve the phylogenomic pioneers: designing novel nuclear markers for genomic DNA extractions of Lepidoptera. Syst Biol 57:231-242

Warchałowski A (2003) Chrysomelidae: The leaf-beetles of Europe and the Mediterranean area. Natura Optima dux Foundation, Warszawa

Wastian L, Unterweger P, Betz O (2016) Influence of the reduction of urban lawn mowing on wild bee diversity (Hymenoptera, Apoidea). J1 Hym Res 49:51-63

White MP, Alcock I, Wheeler BW, Depledge MH (2013) Would you be happier living in a greener urban area? A fixed-effects analysis of Panel Data. Psychol Sci 24(6):920-928

Wickham H (2016) ggplot2: Elegant Graphics for Data Analysis. Springer-Verlag New York. ISBN 978-3-319-24277-4, https:// ggplot2.tidyverse.org

Witsack W (1975) Eine quantitative Keschermethode zur Erfassung der epigäischen Arthropoden-Fauna. Ent Nachr Ber 8:123-128

Wolff D, Gebel M, Geller-Grimm F (2018) Die Raubfliegen Deutschlands. Quelle \& Meyer, Wiebelsheim

Zapata de la Vega JL, Sánchez-Ruiz A (2003) Los representantes ibericos del genero Cidnopus Thomson, 1859 (Coleoptera: Elateridae: Dendrometrinae: Dendrometrini). Bol De La SEA 32:51-58

Publisher's Note Springer Nature remains neutral with regard to jurisdictional claims in published maps and institutional affiliations. 